\title{
Efecto de la refrigeración en la viabilidad y la apoptosis de los adipocitos decantados después de la liposucción
}

\author{
Effect of refrigeration in the viability and apoptosis of decanted adipocytes after \\ liposuction
}

\author{
Gabriel A. Mecott ${ }^{*}$, Hernán Chacón-Martínez ${ }^{1}$, Oscar H. Leal-Torres ${ }^{3}$, Pablo P. Flores-García ${ }^{3}$, \\ Roberto Montes de Oca² y Mauricio M. García-Pérez ${ }^{1}$ \\ ${ }^{1}$ Servicio de Cirugía Plastica y Reconstructiva; ${ }^{2}$ Departamento de Histología; ${ }^{3}$ Facultad de Medicina. Hospital Universitario "Dr. José Eleuterio \\ González", Universidad Autónoma de Nuevo León, Monterrey, Nuevo León, México
}

\begin{abstract}
Objective: To evaluate the effect of refrigeration in the apoptosis and viability of the lipoaspirate in the first $2 \mathrm{~h}$ after harvesting. Methods: 20 consecutive patients who underwent liposuction from the abdomen for esthetic reasons were included. $5 \mathrm{ml}$ of fat were obtained and processed for study. The viability was obtained using trypan blue. Apoptosis was determined using TUNEL assay. Results: All patients were female with a median age of 36.5 (21-67) years. On regard of the viability, at time 0 , the viability in the control group was $59.08 \pm 24 \%$ and $60.96 \pm 22 \%$ in the refrigeration group. At 60 min, the values were $50.82 \pm 21 \%$ versus $55 \pm 32.6 \%(p=0.74)$ and a $120 \mathrm{~min}, 42.69 \pm 20.85 \%$ and $50.33 \pm 21 \%$ respectively. On regard of apoptosis, the percentage of apoptotic cells at time 0 was $37.87 \pm 9.7 \%$ for the control group and $34.28 \pm 9.74 \%$ for refrigerated samples. At $60 \mathrm{~min} 51.11 \pm 8.64 \%$ versus $45.94 \pm 9.15 \%$ and at $120 \mathrm{~min}, 62.97 \pm 13.33 \%$ versus $55.81 \pm 9.45 \%$ respectively. Conclusions: Refrigerating the lipoaspirate at $4{ }^{\circ} \mathrm{C}$ decreased the mortality and apoptosis of the adipocytes in $<10 \%$ within the first $2 \mathrm{~h}$ from harvesting.
\end{abstract}

KEY WORDS: Apoptosis. Refrigeration. Viability. Adipocytes. Liposuction.

\section{Resumen}

Objetivo: Evaluar el efecto de la refrigeración en la apoptosis y la viabilidad del lipoaspirado en las primeras 2 horas después de la toma. Método: Se incluyeron 20 pacientes que fueron sometidas a una liposucción del abdomen por razones estéticas. Se obtuvieron $5 \mathrm{ml}$ de grasa y se procesaron para su estudio. La viabilidad se determinó usando azul tripano. La apoptosis se determinó usando el ensayo TUNEL. Resultados: Todas las pacientes eran mujeres, con una edad media de 36.5 años (rango: 21-67). Con respecto a la viabilidad, en el tiempo 0, en el grupo control fue del $59.08 \pm 24 \%$ y en el grupo de refrigeración fue del $60.96 \pm 22 \%$; a los 60 minutos, los valores fueron del $50.82 \pm 21 \%$ y el $55 \pm 32.6 \%$, respectivamente $(p=0.74)$; y a los 120 minutos, fueron del $42.69 \pm 20.85 \%$ y el $50.33 \pm 21 \%$, respectivamente. En cuanto a la apoptosis, el porcentaje de células apoptóticas en el tiempo 0 fue del $37.87 \pm 9.7 \%$ para el grupo de control y del $34.28 \pm 9.74 \%$ para las muestras refrigeradas; a los 60 minutos, del $51.11 \pm 8.64 \%$ y el $45.94 \pm 9.15 \%$, respectivamente; y a los 120 minutos, del $62.97 \pm$ $13.33 \%$ y el $55.81 \pm 9.45 \%$, respectivamente. Conclusiones: Refrigerar el lipoaspirado a $4{ }^{\circ} \mathrm{C}$ disminuyó la mortalidad y la apoptosis de los adipocitos en menos del 10\% en las primeras 2 horas desde la toma.

PALABRAS CLAVE: Apoptosis. Refrigeración. Viabilidad. Adipocitos. Liposucción.

\author{
Correspondencia: \\ *Gabriel A. Mecott \\ Madero y Gonzalitos, s/n \\ Col. Mitras Centro \\ C.P. 64460 , Monterrey, N.L., México. \\ E-mail: gabriel.mecottrv@uanl.edu.mx
}

Fecha de recepción: 05-09-2018

Fecha de aceptación: 27-05-2019

Cir Cir. 2019;87:619-623 DOI: 10.24875/CIRU.19000705 


\section{Introduction}

Autologous fat grafting, also known as lipotransference, is a widely-used technique with increased interest over time in both aesthetic and reconstructive surgeries ${ }^{1}$. However, despite its good results, retaining the volume of the fat grafts is still a challenge. Reported loss of volume ranges from 40 to $90 \%$ after lipoinjection ${ }^{2-4}$, being this the main disadvantage of fat grafting. The loss of volume is evidently due, at least in part, to death of the grafted cells and further resorption. Thus, preservation of the adipocytes during the process of harvesting, processing and injection is of paramount importance.

The processing of the lipoaspirate depends of the preferences of the surgeon. Different processing techniques includes decantation, washing, filtering and centrifugation, among others. Every technique has their own pros and cons, and different level of damage occurs with all the techniques ${ }^{5-8}$. Despite the chosen method of preparation, with its subsequent quote of damage of the cells, other strategies might improve the rate of viable cells prior grafting.

Refrigeration is a well-known and widely-accepted technique to preserve living tissue, and it has been used to preserve fatty tissue ${ }^{9-11}$. However, the literature about this subject is sparce and contradictory. Lidagoster and and Cols demonstrated that preserved adipocytes had worse viability compared to non preserved cells ${ }^{11}$, whereas Bertossi et al reported good results with cryopreserved adipocytes ${ }^{12}$. Most of the available literature is about cryopreservation of adipocytes for long term and finding the best temperature for that purpose. There are reports of to up to $-100^{\circ} \mathrm{C}^{13}$. Other studies reported viability of adipocytes within few hours after cryopreservation, but using liquid nitrogen at $-140{ }^{\circ} \mathrm{C}^{14}$

Wang and Cols. studied the viability of adipocytes at $2-8{ }^{\circ} \mathrm{C}$ for up to $96 \mathrm{~h}(24-96 \mathrm{~h})$, reporting similar viability in refrigerated versus non refrigerated samples, although they found decreased metabolic activity overtime ${ }^{15}$. Matsumoto and Cols preserved lipoaspirates at room temperature for up to $24 \mathrm{~h}$ and at $4{ }^{\circ} \mathrm{C}$ for 24 to $72 \mathrm{~h}$, to assess morphological changes and metabolic activity ${ }^{13}$. They found no differences in morphology among the samples, but a decrease in metabolic activity over time.

Since these findings are not applicable to the surgical setting, we designed the present study with the purpose to evaluate the effect of refrigeration (at $4{ }^{\circ} \mathrm{C}$ ) in the apoptosis and viability of the lipoaspirate in the first $2 \mathrm{~h}$ after harvesting.

\section{Methods}

20 consecutive patients who underwent liposuction from the abdomen for esthetic reasons were included. Inclusion criteria included adults ( $\geq 18$ yo), any gender, with a body Mass index (BMI) between 18.5 34.9. We excluded patients with history of any chronic disease, with history of any surgery in the abdomen or evidence of infection at the moment of the surgery. Exclusion criteria included samples processed with deviations of the protocol.

The study was approved by the ethics committee of our institution. All patients consented with the processing of their samples.

\section{Lipoaspiration}

The lipoaspirate was obtained from the infra-umbilical area using the tumescent technique. Briefly, modified Klein's solution [1000 cc of Hartmann's solution (PISA, Guadalajara, Mexico) added to $1 \mathrm{mg}$ of epinephrine (PISA, Guadalajara, Mexico)] was infused through a suprapubic incision, using a $12 \mathrm{G}$ infiltration cannula (Byron, Mentor, Santa Barbara, USA).

Liposuction was performed with a liposuction machine (Sound Surgical Technologies, Louisville, CO) and a 3mm Mercedes cannula (Byron, Mentor, Santa Barbara, USA) at 0.5 bar $(-15 \mathrm{mmHg})$ until $30 \mathrm{ml}$ of the aspirate were obtained.

Five $\mathrm{ml}$ of fat were poured in $15 \mathrm{ml}$ Eppendorf tubes (Hauppauge, NY) and decanted for 0, 60, $120 \mathrm{~min}$ for further processing. The control group was decanted at room temperature and the refrigerated group was decanted in a refrigerator (Danby Products, Ontario Canada) at $4{ }^{\circ} \mathrm{C}$ until processed.

\section{Cellular viability assay}

Lipoaspirates were centrifuged at $50 \times \mathrm{g}$ for $5 \mathrm{~min}$ immediately after harvesting, at $1 \mathrm{~h}$ and $2 \mathrm{~h}$ after liposuction. Then, $1 \mathrm{~g}$ of the fat fraction was digested with $0.1 \%$ type 1 collagenase (US Biological, Salem, MA, U.S.A.) and incubated at $37^{\circ} \mathrm{C}$ for $30 \mathrm{~min}$. Digestion was stopped, and the cell suspension was diluted $15: 1$ with $0.4 \%$ trypan blue. Using a Neubauer chamber, adipocytes were counted in 10 random microscopic fields at $40 x$ magnification 


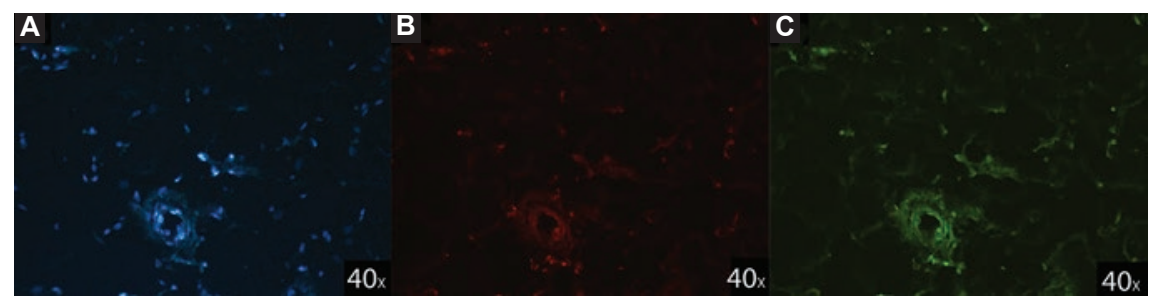

Figure 1. Adipose tissue apoptosis was determined using TUNEL (Terminal deoxynucleotidyl transferase dUTP nick end labeling) assay; A: DAPI test. The nuclei are stained in blue; B: Red Light. Used to identify artifacts; C: FITC (fluorescein isothiocyanate). The apoptotic nuclei are stained and visualized under a fluorescence microscope.

\section{Apoptosis assessment}

Ten $\mathrm{ml}$ of the lipoaspirate was fixed with freshly prepared $4 \%$ paraformaldehyde (Sigma-Aldrich, St. Louis, U.S.A.) in phosphate- buffered saline at 0,60 , and $120 \mathrm{~min}$ after harvesting for standard histological processing. Adipose tissue apoptosis was determined using TUNEL (Terminal deoxynucleotidyl transferase dUTP nick end labeling) assay (TACS TdT in situ fluorescein apoptosis detection Kit; TREVIGEN, Gaithersburg, MD, U.S.A.). The stained nuclei and cells were visualized under a fluorescence microscope. Adipocyte apoptosis in adipose tissue sections was quantified by counting the number of positive nuclei in 10 random microscopic fields at 20x magnification (Fig. 1).

\section{Results}

20 patients were included in the study. There were no patients excluded or samples eliminated. All patients were female with a median age of 36.5 (21-67) yo. On regard of the viability, at time 0 (immediately after the liposuction) the viability of the samples in the control group (room temperature) was $59.08 \pm$ $24 \%$ and $60.96 \pm 22 \%(p=0-85)$ in the refrigeration group. At 60 min after harvesting, the viability of the control group was $50.82 \pm 21 \%$ and $55 \pm 32.6 \%$ $(p=0.74)$ in the refrigeration group. At $120 \mathrm{~min}$, the viability of the control group was $42.69 \pm 20.85 \%$ while in the refrigerated samples was $50.33 \pm 21 \%$ $(p=0.42)$. (Fig. 2)

On regard of Apoptosis, the percentage of positive (apoptotic) cells at time 0 was $37.87 \% \pm 9.7 \%$ for the control group and $34.28 \pm 9.74 \%(p=0.53)$. At $60 \mathrm{~min}$ the values were $51.11 \pm 8.64 \%$ for control group and $45.94 \% \pm 9.15 \%$ for the refrigeration group $(p=0.33)$. At $120 \mathrm{~min}, 62.97 \% \pm 13.33 \%$ of the cells were apoptotic in the control group versus $55.81 \pm 9.45 \%$ in the refrigeration group $(p=0.3)$ (Fig. 3).

\section{Discussion}

Management and preparation of the fat after liposuction are some of the variables included in the fat grafting process, thus, they play an important role in adipocyte survival. Since the viability of the cells decrease overtime once they are deprived from blood supply activity ${ }^{13,16}$ one of the logical actions to decrease death of the cells would be refrigerate them while they are being collected and prepared for grafting.

Refrigeration, as a method of preservation, is known and used since ancient times ${ }^{17,18}$ and is one of the basic preservations techniques in laboratories allover the word. Thus, we conducted this study to assess if refrigeration would decrease the death or apoptosis in the adipocytes while they are being prepared for grafting.

As we mentioned previously, there are several studies about cryopreservation of the fat, but most of them were orientated to preserve large amount of fat for a long time, seeking reinjection of the preserved fat in a second surgery. This approach is evidently non-applicable to the common surgical setting where the fat should be grafted within the first couple of hours. Nevertheless, they showed some interesting data that could be pertinent for our study. The studies of Wang and Matsumoto reported short-term viability or morphology of adipocytes, reporting similar results with refrigerated vs non-refrigerated samples ${ }^{13,15}$.

We decided to study viability and apoptosis of the adipocytes because we believe that this will allow us to see the "full picture" of the damage of the cells. That is, viability assessment might show live cells (metabolically active) but in the process of apoptosis, masking some damage of the cells. Furthermore, the refrigeration, if effective, could decrease mortality or apoptosis of the cells, making relevant to assess both aspects.

The results showed that refrigerated samples had better survival than those left at room temperature, and 


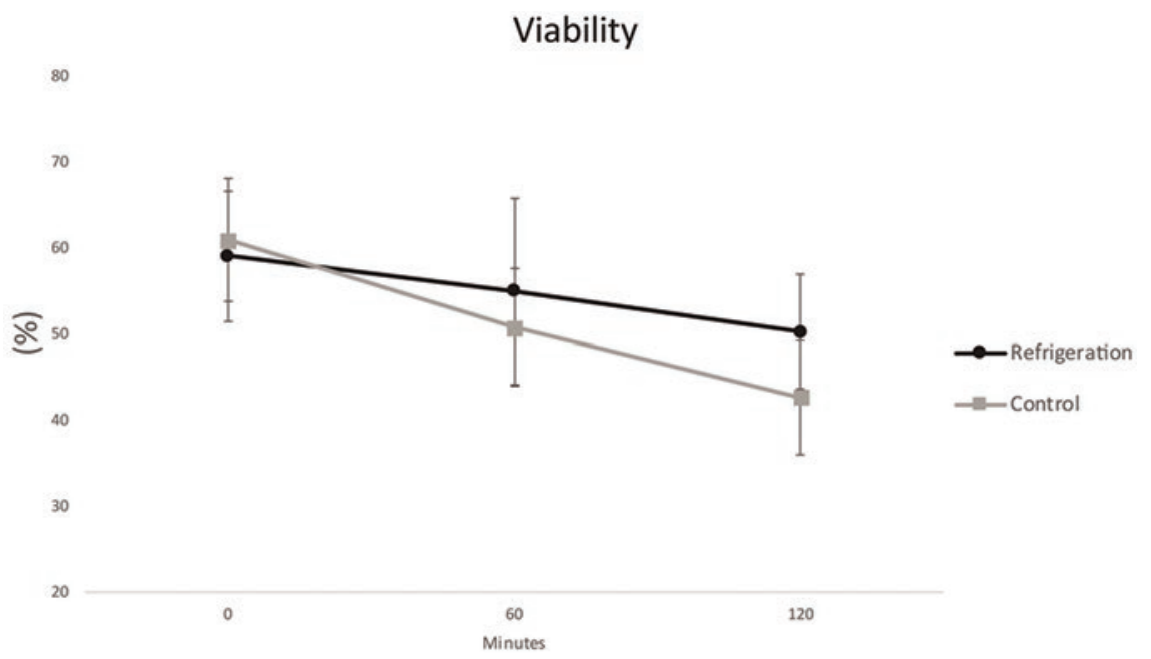

Figure 2. Viability. Refrigerated samples had better viability when compared to samples at room temperature. The difference between the groups increased at each time $(p>0.05)$ (see text for details).

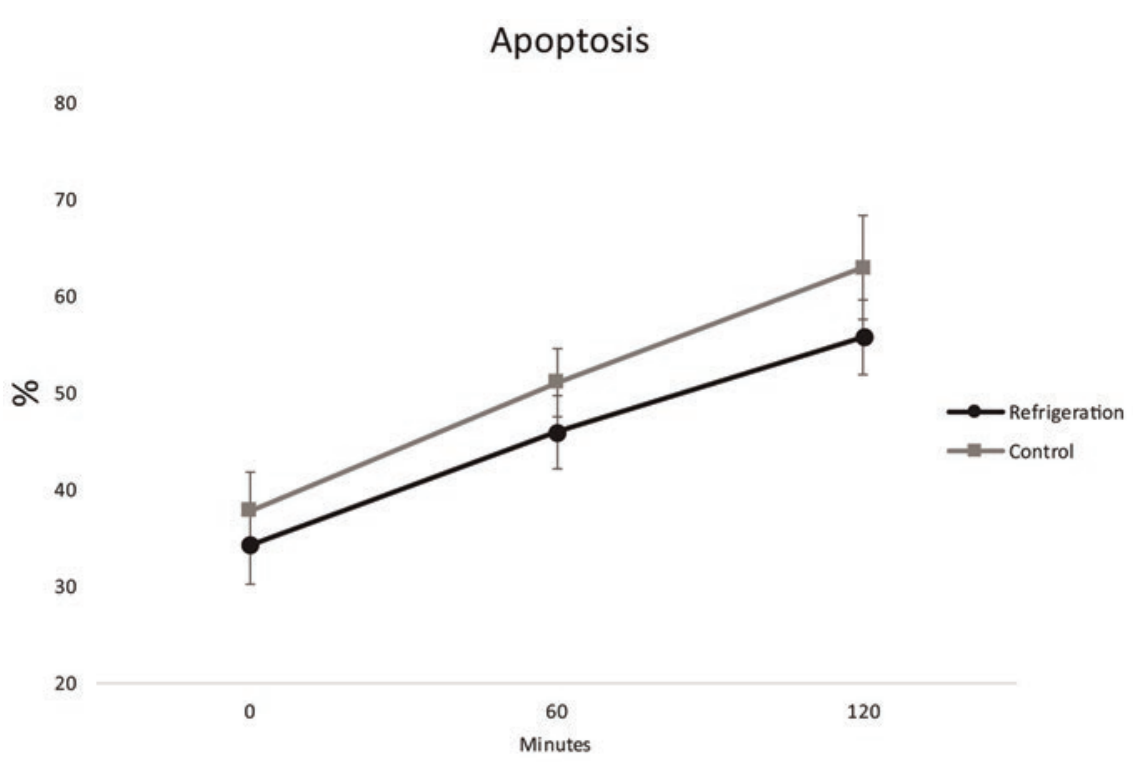

Figure 3. Apoptosis. Apoptosis increased during the study. Refrigeration decreased apoptosis at 60 and 120 min after liposuction. Difference was not significant $(p>0.05)$ (See text for details).

the difference increased over time. However, the difference was only $5 \%$ at $60 \mathrm{~min}$ and $8 \%$ at $120 \mathrm{~min}$, being not significant (Figure 2). The apoptosis showed similar results, with difference of $6 \%$ the 1 rst hour and $7 \%$ at the $2^{\text {nd }}$ hour. Again, no significance was achieved $(p>0.05)$ (Fig. 3). With these results, we calculated the sample size required to achieve significance, obtaining a number of 392 patients per group. We believe that the difference between means is so short that there is no point to extend the number of patients in order to achieve significance.

The tendency or our results is that at longer time, more difference between refrigerated vs non-refrigerated samples, according to the existing literature ${ }^{9-13,19}$.
However, we limited the timepoints up to 120 min because that would be a reasonable time for harvesting fat in a common liposuction. Looking for the effect at longer time is beyond the scope of the article.

Based on our results, we believe that refrigeration can improve viability and decrease apoptosis of the adipocytes, but in less than $10 \%$ at $2 \mathrm{~h}$. Then, everyone should balance this benefit versus the investment in equipment and implementing of the process for that purpose within the operating room.

It is evident that, in some cases, the liposuction could be extended beyond $2 \mathrm{~h}$; and this protocol did not describe the effect of refrigeration during this time, which would have been interesting. However, we 
decided to limit our study to $2 \mathrm{~h}$ because in a previous study, we demonstrated that viability decreased to $50 \%$ at two hours ${ }^{20}$.

Therefore, we believe that it would not be convenient to decant the aspirate for longer time. Then, we did not consider to extend the study for more than $120 \mathrm{~min}$.

\section{Conclusions}

Refrigerating the lipoaspirate at $4{ }^{\circ} \mathrm{C}$ decreased the mortality and apoptosis of the adipocytes in less than $10 \%$ within the first $2 \mathrm{~h}$ from harvesting. Larger studies are necessary to achieve significance.

\section{Conflicts of interest}

The authors declare that there is no conflict of interest regarding the publication of this article.

\section{Ethical disclosures}

Protection of human and animal subjects. The authors declare that the procedures followed were in accordance with the regulations of the relevant clinical research ethics committee and with those of the Code of Ethics of the World Medical Association (Declaration of Helsinki).

Confidentiality of data. The authors declare that they have followed the protocols of their work center on the publication of patient data.

Right to privacy and informed consent. The authors have obtained the written informed consent of the patients or subjects mentioned in the article. The corresponding author is in possession of this document.

\section{References}

1. Pu LL, Yoshimura K, Coleman SR. Future Perspectives of Fat Grafting. Clin Plast Surg 2015;42:389-394, ix-X.

2. Peer LA. The neglected free fat graft, its behavior and clinical use. Am J Surg 1956;92:40-47.

3. Chajchir A. Fat injection: long-term follow-Up. Aesthetic Plast Surg 1996;20:291-296.

4. Mikus JL, Koufman JA, Kilpatrick SE. Fate of liposuctioned and purified autologous fat injections in the canine vocal fold. Laryngoscope 1995;105:17-22.

5. Ferraro GA, De Francesco F, Tirino V, et al. Effects of a new centrifugation method on adipose cell viability for autologous fat grafting. Aesthetic Plast Surg 2011;35:341-348.

6. Conde-Green A, Wu I, Graham I, et al. Comparison of 3 techniques of fat grafting and cell-supplemented lipotransfer in athymic rats: a pilot study. Aesthet Surg J 2013;33:713-721.

7. Conde-Green A, de Amorim NF, Pitanguy I. Influence of decantation, washing and centrifugation on adipocyte and mesenchymal stem cell content of aspirated adipose tissue: a comparative study. J Plast Reconstr Aesthet Surg 2010;63:1375-1381.

8. Khater R, Atanassova P, Anastassov Y, Pellerin P, Martinot-Duquennoy V. Clinical and experimental study of autologous fat grafting after processing by centrifugation and serum lavage. Aesthetic Plast Surg 2009;33:37-43.

9. Erdim M, Tezel E, Numanoglu A, Sav A. The effects of the size of liposuction cannula on adipocyte survival and the optimum temperature for fat graft storage: an experimental study. J Plast Reconstr Aesthet Surg 2009:62:1210-1214.

10. Wolter TP, von Heimburg D, Stoffels I, Groeger A, Pallua N. Cryopreservation of mature human adipocytes: in vitro measurement of viability. Ann Plast Surg 2005;55:408-413.

11. Lidagoster MI, Cinelli PB, Levee EM, Sian CS. Comparison of autologous fat transfer in fresh, refrigerated, and frozen specimens: an animal model. Ann Plast Surg 2000;44:512-515

12. Bertossi D, Kharouf S, d'Agostino A, et al. [Facial localized cosmetic filling by multiple injections of fat stored at -30 degrees $\mathrm{C}$. Techniques, clinial follow-up of 99 patients and histological examination of 10 patients]. Ann Chir Plast Esthet 2000;45:548-555; discussion 555-546.

13. Matsumoto D, Shigeura T, Sato $K$, et al. Influences of preservation at various temperatures on liposuction aspirates. Plast Reconstr Surg 2007; 120:1510-1517.

14. Cui XD, Gao DY, Fink BF, Vasconez HC, Pu LL. Cryopreservation of human adipose tissues. Cryobiology 2007:55:269-278.

15. Wang WZ, Fang $\mathrm{XH}$, Williams SJ, et al. The impact of short-term refrigeration of human lipoaspirate on adipose-derived stem cells and adipocytes. J Plast Reconstr Aesthet Surg 2015:68:137-139.

16. Boschert MT, Beckert BW, Puckett CL, Concannon MJ. Analysis of lipocyte viability after liposuction. Plast Reconstr Surg 2002;109:761-765; discussion 766-767.

17. Neuburger A. The technical arts and sciences of the ancients. London, 2003.

18. Anderson OE. Refrigeration in America; a history of a new technology and its impact. Princeton: Published for the University of Cincinnati by Princeton University Press, 1953.

19. Wang WZ, Fang XH, Williams SJ, et al. The effect of lipoaspirates cryopreservation on adipose-derived stem cells. Aesthet Surg J 2013;33:1046-1055.

20. Mecott GA, Gonzalez IZ, montes de Oca R, et al. Effect of Decantation Time on Viability and Apoptosis in Adipocytes After Liposuction. Aesthetic Plast Surg. 2019 Feb;43(1):228-232. 